\title{
OPTIMAL PIEZOELECTRIC SHUNT DAMPER USING ENHANCED SYNTHETIC INDUCTOR: SIMULATION AND EXPERIMENTAL VALIDATION
}

\author{
MuHammad Nazri Suhaimi, AZni Nabela WAHID*, \\ NOR HIDAYATI DIYANA NORDIN AND KHAIRUL AFFENDY MD NOR \\ Smart Structure System \& Control Lab (S3CRL), Mechatronics Engineering Department, \\ International Islamic University Malaysia, \\ Jalan Gombak, 53100 Kuala Lumpur, Malaysia \\ *Corresponding author: azni@iium.edu.my
}

(Received: $4^{\text {th }}$ March 2021; Accepted: $17^{\text {th }}$ June 2021; Published on-line: $4^{\text {th }}$ January 2022)

\begin{abstract}
Piezoelectric material has the ability to convert mechanical energy to electrical energy and vice versa, making it suitable for use as an actuator and sensor. When used as a controller in sensor mode, the piezoelectric transducer is connected to an external electrical circuit where the converted electrical energy will be dissipated through Joule heat; also known as piezoelectric shunt damper (PSD). In this work, a PSD is used to dampen the first resonance of a cantilever beam by connecting its terminal to an $R L$ shunt circuit configured in series. The optimal resistance and inductance values for maximum energy dissipation are determined by matching the parameters to the first resonant frequency of the cantilever beam, where $R=78.28 \mathrm{k} \Omega$ and $L=2.9 \mathrm{kH}$ are found to be the optimal values. To realize the large inductance value, a synthetic inductor is utilized and here, the design is enhanced by introducing a polarized capacitor to avoid impedance mismatch. The mathematical modelling of a cantilever beam attached with a PSD is derived and simulated where $70 \%$ vibration reduction is seen in COMSOL. From experimental study, the vibration reduction obtained when using the piezoelectric shunt circuit with enhanced synthetic inductor is found to be $67.4 \%$ at $15.2 \mathrm{~Hz}$. Results from this study can be used to improve PSD design for structural vibration control at targeted resonance with obvious peaks.
\end{abstract}

ABSTRAK: Material piezoelektrik mempunyai keupayaan mengubah tenaga mekanikal kepada tenaga elektrik dan sebaliknya, di mana ia sesuai digunakan sebagai penggerak dan pengesan. Apabila digunakan sebagai alat kawalan dalam mod pengesan, piezoelektrik disambung kepada litar elektrik luaran di mana tenaga elektrik yang ditukarkan akan dibebaskan sebagai haba Joule; turut dikenali sebagai peredam alihan piezoelektrik (PSD). Kajian ini menggunakan PSD sebagai peredam resonan pertama pada palang kantilever dengan menyambungkan terminal kepada litar peredam $R L$ bersiri. Rintangan optimal dan nilai aruhan bagi tenaga maksimum yang dibebaskan terhasil dengan membuat padanan parameter pada frekuensi resonan pertama palang kantilever, di mana $R=78.28 \mathrm{k} \Omega$ dan $L$ $=2.9 \mathrm{kH}$ adalah nilai optimum. Bagi merealisasikan nilai aruhan besar, peraruh buatan telah digunakan dan di sini, rekaan ini ditambah baik dengan memperkenalkan peraruh polaris bagi mengelak ketidakpadanan impedans. Model matematik palang kantilever yang bersambung pada PSD telah diterbit dan disimulasi, di mana $70 \%$ getaran berkurang pada COMSOL. Hasil dapatan eksperimen ini menunjukkan pengurangan getaran yang terhasil menggunakan litar peredam piezoelektrik bersama peraruh buatan menghasilkan $67.4 \%$ pada $15.2 \mathrm{~Hz}$. Hasil dapatan kajian ini dapat digunakan bagi membaiki rekaan PSD berstruktur kawalan getaran iaitu pada resonan tumpuan di puncak ketara. 
KEYWORDS: vibration control; piezoelectric shunt damper (PSD); synthetic inductance

\section{INTRODUCTION}

In applications for vibration control, a piezoelectric patch can be perfectly bonded to a vibrating mechanical structure to supply equal and opposite force to its host structure (active control) or dissipate the mechanical energy via joule heat (passive control). In the latter case, whenever the host structure vibrates, an electrical charge will accumulate in the piezoelectric material and this energy can be dissipated as Joule heat if the patch terminal is connected to an external shunt circuit matched to the mechanical resonance of its host structure; also known as piezoelectric shunt damping. This results in vibration suppression equivalent to a tuned mass damper in a mechanical system.

The concept of electromechanical damping using a piezoelectric shunt damper was introduced by Hagood Von Flotow in 1991 [1] and ever since, there have been various studies conducted due to its potential and versatility in various applications requiring suppression; for example in aircraft [2], marine [3] or railway vehicles [4], and many more. For maximum energy dissipation to occur, the shunt circuit needs to be tuned to the targeted resonant frequency of the host structure, and the simplest form of circuit available uses resistor-inductor $(R L)$ components, equivalent to mass-springs in mechanical systems. The electrical impedance of the shunt circuit matched with the mechanical resonance typically will have a significantly large inductance value. To realize this, a synthetic inductor circuit is introduced using op-amps. Although this method has been proven to be successful [5-9], there are areas of improvement that can be made in terms of its efficiency. One of the problems that arise is the large internal resistance developed in the synthetic inductor circuit to generate the huge inductance. As a result, the resistance developed usually exceeds the optimum resistance value required to suppress the matched vibration mode, thereby creating a mismatch in the circuit impedance. To alleviate this, the concept of enhanced shunt circuit will be applied, where an additional capacitor will be added in parallel to the shunt circuit $[10,11]$.

In this work, a resonant-type piezoelectric shunt damper on a cantilever beam will be studied and the optimal shunt circuit will be constructed. In section 2, the mathematical model of a cantilever beam attached with a PSD in series configuration is presented. The optimal values of resistance, $R$ and inductance, $L$ for the shunt circuit is also derived and shown. Following that, simulation studies are carried out in section 3 to show the performance of the PSD in suppressing the first resonant by using COMSOL Multiphysics software. Since the value of inductance, $L$ will be large, an enhanced synthetic inductor method will be adopted and shown in section 4 where experimental study is also carried out to validate the findings.

\section{MATHEMATICAL MODELLING}

\subsection{Modelling of the Piezoelectric Shunt Damper System}

The piezoelectic constitutive equation can be written as follows [12]:

$$
\left\{\begin{array}{l}
T \\
D
\end{array}\right\}=\left[\begin{array}{cc}
c^{E} & -e \\
e^{t} & \varepsilon
\end{array}\right]\left\{\begin{array}{l}
S \\
E
\end{array}\right\}
$$

where $T$ is a stress vector, $D$ is an electric displacement vector, $S$ is a strain vector, $E$ is an electric field vector, $c^{E}$ is an elasticity stiffness matrix evaluated at constant electric field, $e$ is a piezoelectric stress matrix, $\varepsilon^{S}$ is a dielectric matrix evaluated at a constant mechanical 
strain, $t$ is a matrix transpose. The coupled cantilever beam-piezoelectric equation can be derived after applying Hamilton's principle to obtain the following electromechanical system $[13,14]$ :

$$
\left[\begin{array}{cc}
M & 0 \\
0 & 0
\end{array}\right]\left\{\begin{array}{c}
\ddot{w} \\
\ddot{v}
\end{array}\right\}+\left[\begin{array}{cc}
C & 0 \\
0 & 0
\end{array}\right]\left\{\begin{array}{c}
\dot{w} \\
\dot{v}
\end{array}\right\}+\left[\begin{array}{cc}
K & \Theta \\
\Theta^{t} & -C_{P}
\end{array}\right]\left\{\begin{array}{l}
w \\
v
\end{array}\right\}=\left\{\begin{array}{l}
F \\
q
\end{array}\right\}
$$

where $[M]$ is a global mass matrix, $[C]$ is a global damping matrix, $[K]$ is a global stiffness matrix, $\left[C_{P}\right]$ is an inherent piezoelectric capacitance matrix, $[\Theta]$ is an electromechanical coupling matrix of the host structure and piezoelectric material, $\{F\}$ is an applied mechanical force vector, $\{q\}$ is an electric charge vector, $\{w\}$ is a generalized mechanical coordinate and $\{v\}$ is a generalized electrical coordinate. The shunt damping voltage can be represented by the current-voltage relationship in the Laplace domain when the piezo patch is shunted by an impedance, as illustrated in Fig. 1.

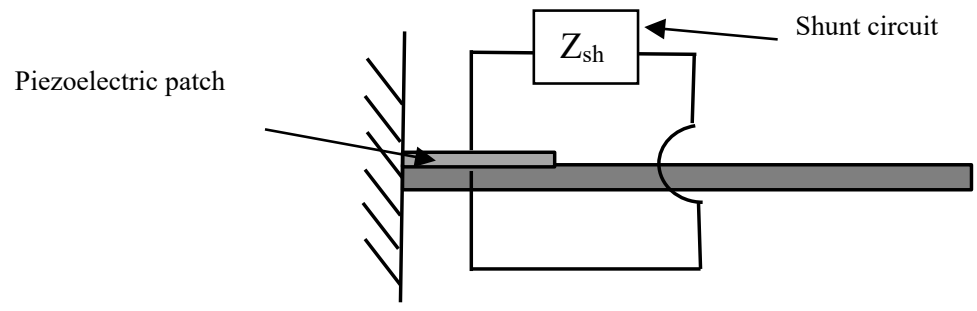

Fig. 1: Illustration of a cantilever beam attached with piezoelectric shunt damper (PSD).

$$
V_{s h}(s)=Z_{s h}(s) \cdot I_{s h}(s)
$$

where $V_{s h}(s)$ is the voltage across the impedance; $I s h(s)$ is the current flowing through the shunt circuit; $Z_{s h}$ is the shunt impedance and $s$ is a Laplace operator. Differentiating electric potential, $q$ in Eq. (2) and substituting into Eq. (3), the following is obtained:

$$
\begin{gathered}
V_{s h}(s)=Z_{s h}(s) \cdot \dot{q}(s)=Z_{s h}(s) \cdot\left([\Theta]^{t}\{w\} s\right. \\
\left.-\left[C_{P}\right] V_{s h}(s) s\right)
\end{gathered}
$$

Rearranging Eq. (4),

$$
V_{s h}(s)=\frac{Z_{s h}(s)[\Theta]^{t}\{w\} s}{1+Z_{s h}(s)\left[C_{p}\right] s}
$$

Finally, substituting Eq. (5) into Eq. (2), the total equation of motion for a cantilever beam attached with a piezoelectric patch connected to a shunt circuit is obtained as follows:

$$
[M]\{\ddot{w}\}+\left(Z_{\text {total }}[\Theta][\Theta]^{t}\right)\{\dot{w}\}+[K]\{w\}=\{F\}
$$

The term $Z_{\text {total }}$ is the total electrical impedance of the shunt circuit where:

$$
Z_{\text {total }}=\frac{Z_{s h}}{1+Z_{s h}\left[C_{p}\right] s}
$$

If the electrical impedance for the shunt circuit is in series configuration, $Z_{s h}^{s}$, it can be written as,

$$
Z_{s h}^{S}=L_{S}^{*} S+R_{S}^{*}
$$


where $L_{S}^{*}$ and $R_{S}^{*}$ are the optimal inductance and resistance, respectively. Both can be written as follows [7]:

$$
L_{S}^{*}=\frac{1}{C_{P}^{S}\left(\omega_{S} \delta_{S}^{*}\right)^{2}} ; \quad R_{S}^{*}=\frac{r_{S}^{*}}{\omega_{S} C_{P}^{S}}
$$

where $C_{P}^{S}$ is the piezo capacitance at constant strain, $C_{P}^{S}=C_{P}^{T}\left(1-k_{31}{ }^{2}\right)$, and $C_{P}^{T}$ is the piezo capacitance at constant stress,

$$
C_{P}^{T}=\frac{K_{3}^{T} \times \varepsilon_{o} \times A_{P}}{t_{p}}
$$

All the terms in Eq. (10) are dependent on the type of piezoelectric patch used where $K_{3}^{T}, \varepsilon_{o}, A_{P}$ and $t_{p}$ are the relative dielectric constant, relative permittivity of free space, area of the patch, and thickness of the patch, respectively. The terms $\delta_{s}^{*}$ and $r_{s}^{*}$ in Eq. (9) are the optimal tuning ratio and optimal damping ratio for series configuration, which are dependent on the piezo electromechanical coupling coefficient for a transverse mode $31, k_{31}$ :

$$
\delta_{s}^{*}=\sqrt{1+k_{31}^{2}} ; \quad r_{s}^{*}=\sqrt{2} \frac{k_{31}}{1+k_{31}{ }^{2}}
$$

The coefficient $k_{31}$ describes the conversion of energy by the piezo element from electrical to mechanical and vice versa. It can be derived in several ways; one of them is using resonant frequency change with respect to the electric boundary conditions,

$$
k_{31}=\sqrt{\left(\omega_{o}^{2}-\omega_{s}^{2}\right) / \omega_{s}^{2}}
$$

where $\omega_{o}$ and $\omega_{s}$ are natural frequencies of the beam when the piezoelectric patch is in open circuit and short circuit condition, respectively. In this work, these values will be obtained experimentally, which will be discussed in Section 4. For this work, the electromechanical coupling value for this specific piezoelectic patch is found to be $k_{31}=0.196$.

The total electrical impedance in series, $Z_{\text {total }}^{S}$ as shown in Eq. (6) can be re-written as,

$$
Z_{\text {total }}^{s}=\frac{L_{s}^{*} s+R_{s}^{*}}{L_{s}^{*} C_{p} s^{2}+R_{s}^{*} C_{p} s+1}
$$

The values found for the optimal parameters, as discussed above, are tabulated in Table 1.

The optimal resistance and inductance in Table 1 make up the electrical impedance of the series shunt circuit in order to dissipate the mechanical energy of the host structure at first resonant frequency. These values will be constructed using physical $R L$ components where evidently, the resistance value can be realized by using off-the-shelf resistors, however this is not the case for the inductor. Since inductor value typically ranges from $1 \mu \mathrm{H}$ to $20 \mathrm{H}$, an enhanced synthetic inductor will be implemented to acquire inductance in the range of $\mathrm{kH}$.

Table 1: Values of optimal tuning and damping ratio and optimal resistance and inductance calculated using Eqs. (9) and (11)

\begin{tabular}{cc}
\hline & Series shunt circuit \\
\hline Optimal tuning ratio, $\boldsymbol{\delta}^{*}$ & 1.0197 \\
Optimal damping ratio, $\boldsymbol{r}^{*}$ & 0.2715 \\
Optimal resistor, $\boldsymbol{R}^{*}, \boldsymbol{\Omega}$ & $78.28 \times 10^{3}$ \\
Optimal inductor, $\boldsymbol{L}^{*}, \mathbf{H}$ & 2902.9 \\
\hline
\end{tabular}




\section{SIMULATION STUDIES}

For simulation study, a stainless-steel cantilever beam with dimensions of $280 \mathrm{~mm} x$ $40 \mathrm{~mm} \times 2 \mathrm{~mm}$ is used. A PZT-5A piezoelectric patch with $50 \mathrm{~mm} \times 20 \mathrm{~mm} \times 0.38 \mathrm{~mm}$ dimension is attached at the fixed end of the beam. The terminal of the piezoelectric patch is connected to an optimal $R L$ circuit in series configuration as found in Table 1. The damping performance of the PSD will be investigated where the difference between the displacement of the beam at its first resonant frequency, without damping and with damping is compared. For this, the circuit is made open so there will be no current passing through i.e. the shunt damping circuit is not connected and is hereby considered as a no-damping condition. And when the circuit is made closed, current can pass through the shunt damping circuit and this is when damping condition exists.

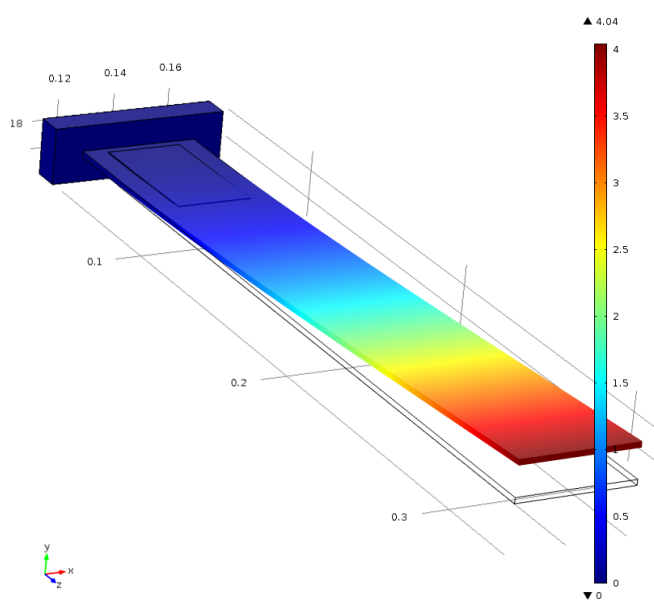

Fig. 2: Cantilever beam attached with piezoelectric patch at its fixed end modelled in COMSOL.

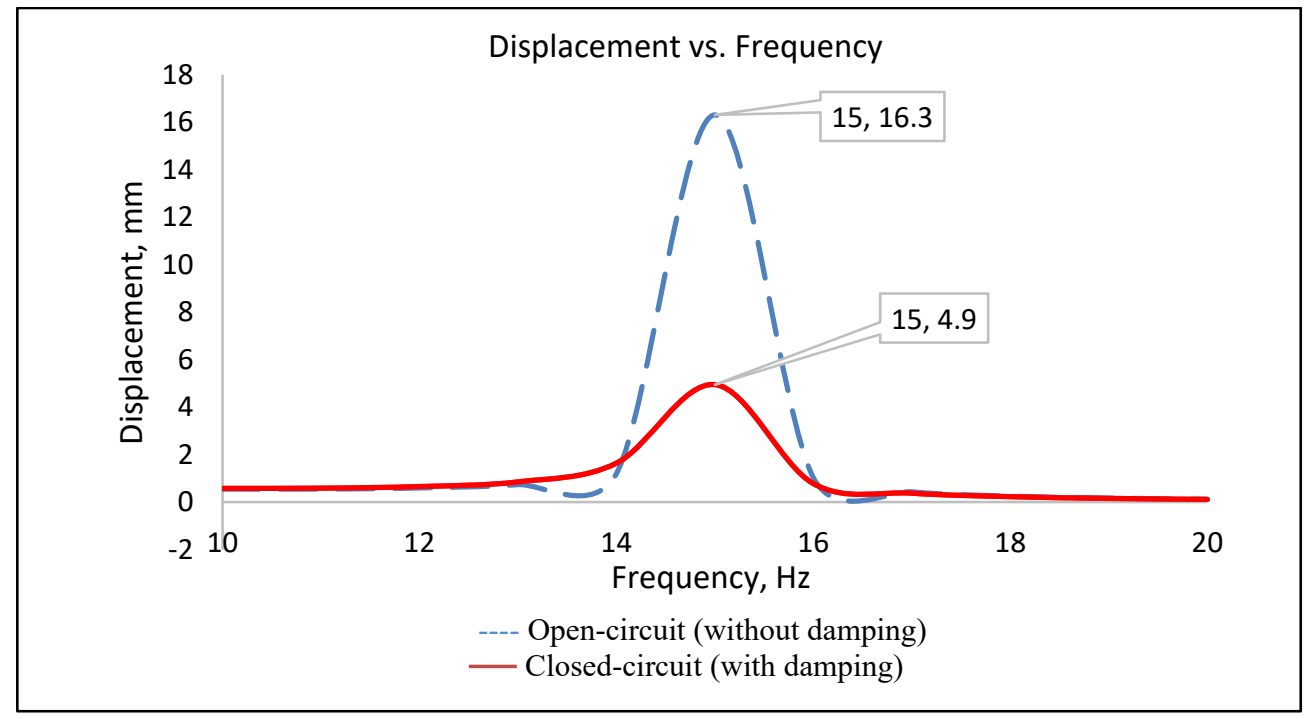

Fig. 3: Comparison of the beam displacement amplitude at first resonance (blue-dashed: open circuit, red-solid: closed-circuit) using COMSOL.

Figure 3 shows the response of the beam-PSD system simulated via COMSOL where the terminal of the piezoelectric is set as 'floating potential' and 'terminal' for open and close circuit condition, respectively. A series $R L$ circuit following the values found in Table 1 is connected to the terminal as the optimal shunt circuit. The displacement of the cantilever beam is plotted at a frequency range that covers its first resonant frequency. The responses 
when PSD is in open circuit (without damping) and closed circuit (with damping) conditions are plotted and compared to see the PSD damping performance. From the figure, the difference between the displacement peak i.e. vibration reduction is recorded to be $70 \%$ in COMSOL.

\section{OPTIMAL SHUNT CIRCUIT CONSTRUCTION}

\subsection{Equation of Input Impedance for Synthetic Inductor}

To realize the significantly large value of inductance, a synthetic inductor is constructed utilizing two op-amps, three resistors, and a capacitor with some voltage being supplied to the op-amps. To calculate the input impedance of the synthetic inductor, a few conditions must be stated. First, the op-amp is assumed to be ideal, so that the input impedance of the amplifier is infinitely high. This caused the current at input terminal to be zero. Secondly, the voltage gain is infinitely high, therefore the voltage across input terminal is zero while output voltage remained finite [9].

$$
Z_{\text {in }}=j \omega \frac{R_{1} R_{3} R_{5} C_{4}}{R_{2}}
$$

From Eq. (14), it is shown that the circuit has the same characteristics as an ideal inductor. Rearranging Eq. (14),

$$
L=\frac{R_{1} R_{3} R_{5} C_{4}}{R_{2}}
$$

Essentially, the desired inductance can be changed by changing the value of $R_{2}$ accordingly. The optimal inductance, $L$ value for maximum energy dissipation was found earlier to be 2902.9 H. Following Eq. (14), the resistance values for resistors $R_{1}, R_{3}$, and $R_{5}$ are chosen to be $97.4 \mathrm{k} \Omega, 101.1 \mathrm{k} \Omega$ and $95 \mathrm{k} \Omega$, respectively and achieved using potentiometers. For $C_{4}$, a $1 \mu \mathrm{F}$ capacitor is used. Therefore, the value of $R_{2}$ needs to be $322,260 \Omega$ to achieve the desired optimal inductance, $L$.

\subsection{Enhanced Shunt Circuit Implementation}

Although physically doable, one of the problems that arise is the large internal resistance developed in the synthetic inductor circuit to generate the huge inductance. From this, the developed resistance exceeds the optimum resistance value required to suppress the matched vibration mode, therefore creating a mismatch in the circuit impedance. Utilizing the concept of enhanced shunt circuit $[10,11]$, an additional capacitor will be added in parallel to the shunt circuit to increase the capacitance of the piezoelectric patch. In this case, a $4.7 \mathrm{mF}$ capacitor (i.e. polarized capacitor) is connected in parallel to $55 \mathrm{nF}$ piezoelectric, creating an equivalent capacitor of, $C_{e q}=C_{\text {piezo }}+C_{\text {capacitor }}$.

The schematic of the shunt circuit to be constructed is shown in Fig. 4 using the values obtained in Table 1. From Fig. 4, the shunt circuit consists of a resistor in series with a synthetic inductor, connected in parallel with a $4.7 \mathrm{mF}$ polarized capacitor and the piezoelectric patch, where the patch can be modelled as a capacitor having an inherent capacitance of $55 \mathrm{nF}$. Figure 5 shows the physical implementation of the shunt circuit. 


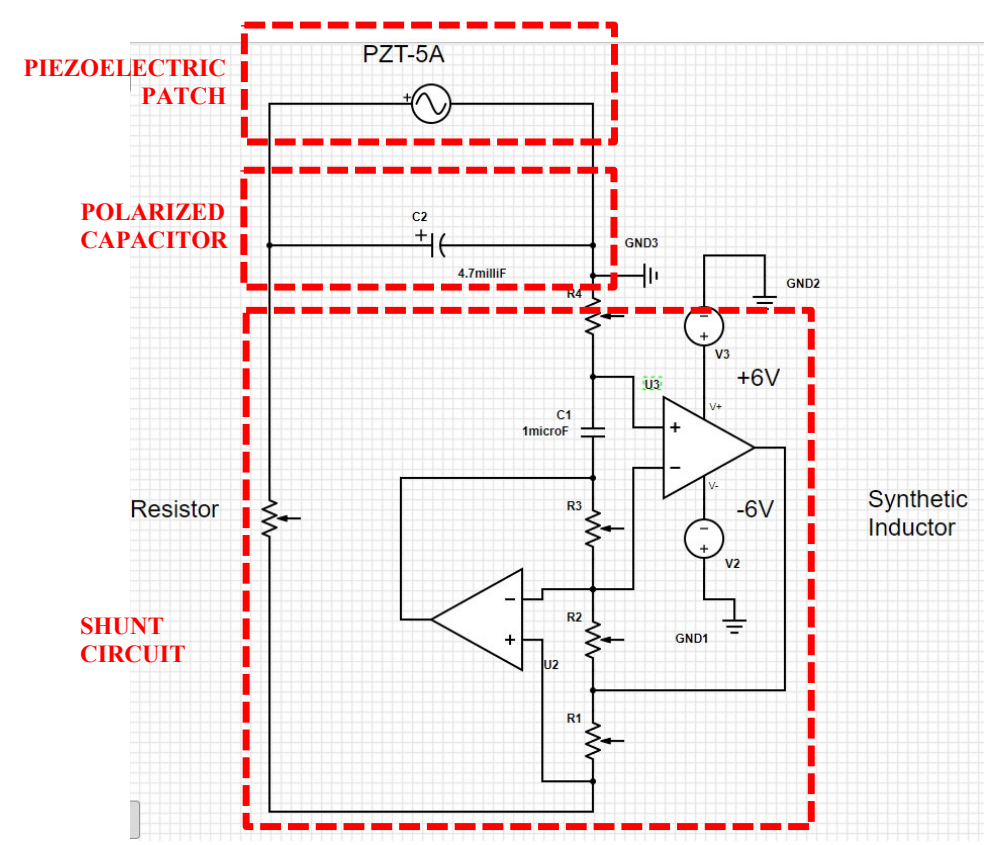

Fig. 4: Schematic of the piezo patch attached with optimal $R L$ shunt circuit in series utilizing a synthetic inductor.

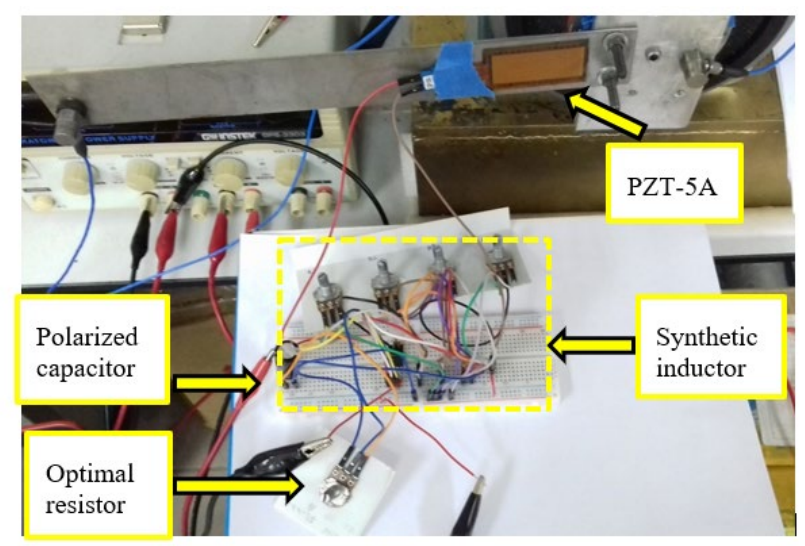

Fig. 5: Experimental setup of the piezo patch attached with optimal $R L$ shunt circuit in series utilizing a synthetic inductor.

\section{EXPERIMENTAL STUDIES}

The complete setup of the experiment is shown in Fig. 6. Here, a piezoelectric patch is bonded on the surface of cantilever beam using a thin layer of epoxy adhesive. The position of the patch is near the fixed end of the beam as this is where the largest stress and strain is generated when it deflects. In this study, the piezoelectric patch used is QuickPack model QP10N made from PZT-5A (3195HD material type). The dimensions of the beam and piezoelectric patch used are shown in Table 2. The end of the beam is clamped to an ET139 electrodynamic shaker with two accelerometers mounted at the free end and at the clamped end of the beam to measure the output and input to the system, respectively. The piezoelectric terminals are connected to the optimal shunt circuit as constructed in Section 3. 


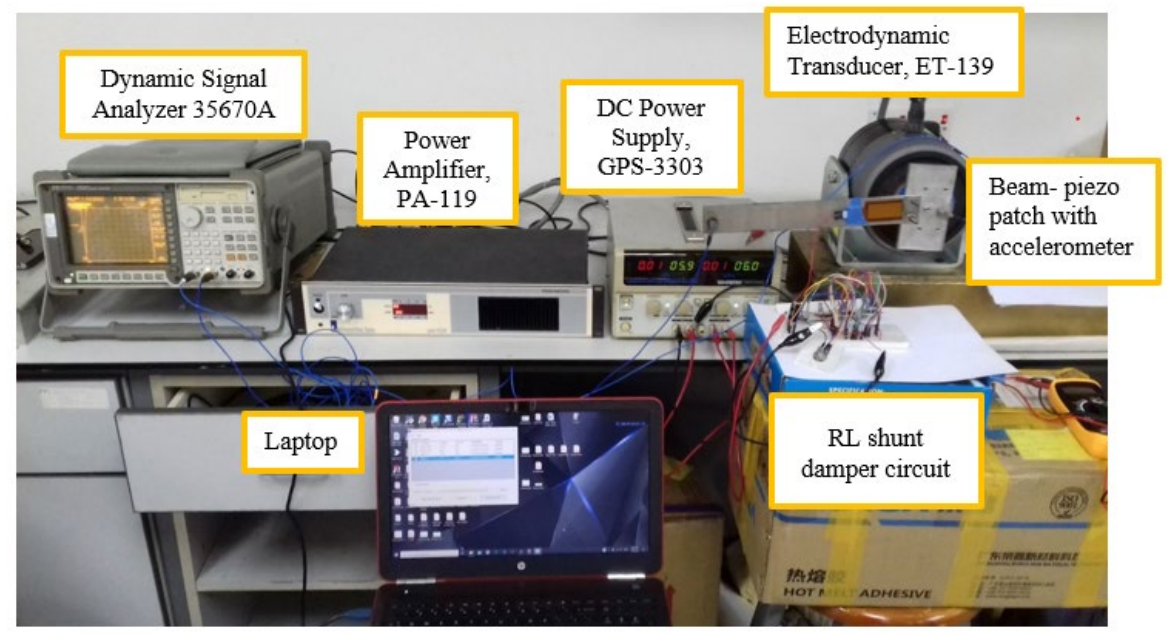

Fig. 6: The complete experimental setup for vibration control using optimal piezoelectric shunt damper.

Table 2: The dimensions of beam and piezoelectric patch used in experiment

\begin{tabular}{ccccc}
\hline & Length, $\mathbf{m}$ & Width, $\mathbf{m}$ & Thickness, $\mathbf{m}$ & Material \\
\hline Beam & 0.28 & 0.04 & 0.002 & Stainless steel \\
Piezoelectric patch & 0.04597 & 0.02057 & 0.000381 & PZT-5A (3195HD) \\
\hline
\end{tabular}

\subsection{Determining Short Circuit Natural Frequency, $\omega_{\mathrm{s}}$ and Open Circuit Natural Frequency, $\omega_{0}$}

The purpose of determining short circuit natural frequency, $\omega_{s}$ and open circuit natural frequency, $\omega_{o}$ is to determine the electromechanical coupling, $k_{3 l}$ of the piezoelectric patch, as stated in Eq. (12). Here, the open circuit natural frequency is obtained when the beamPSD system is excited at its first natural frequency where the terminal is left open; while for short circuit natural frequency, the piezoelectric terminal is put in short circuit condition by connecting a wire through both terminals. Figure 7 shows the frequencies obtained for each case.
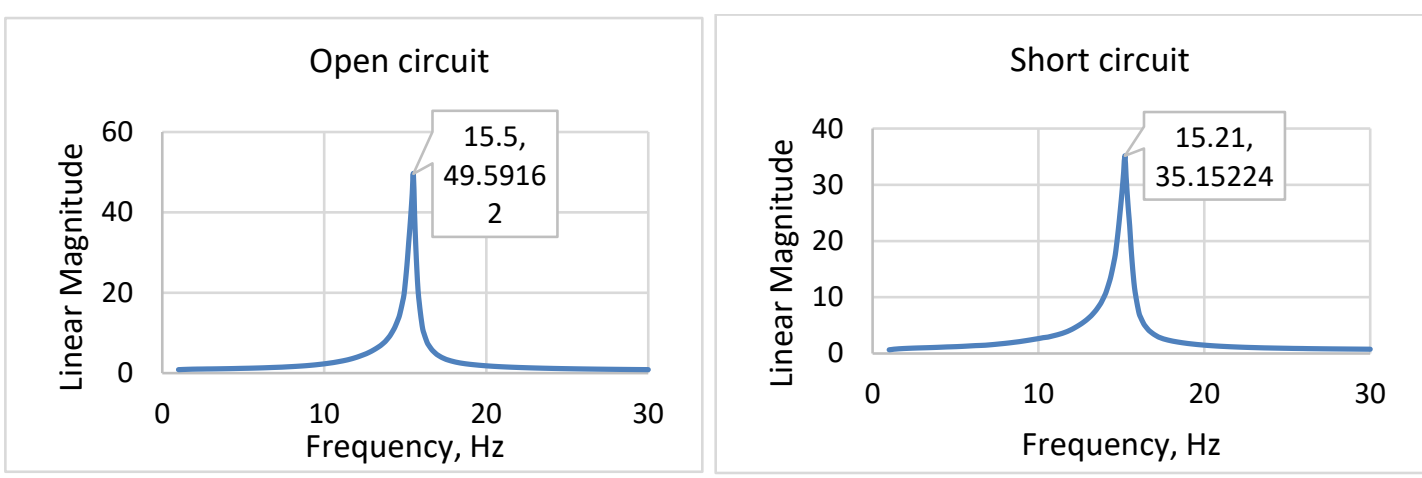

Fig. 7: Natural frequency in open-circuit (left) and short-circuit (right) condition, $\omega_{o}=15.50 \mathrm{~Hz}$ and $\omega_{s}=15.21 \mathrm{~Hz}$, respectively.

From these values, it is determined that electromechanical coupling value for this specific piezoelectic patch to be $k_{31}=0.196$ which will be used throughout the work. 


\subsection{Vibration Control of Cantilever Beam with Optimal PSD}

The performance of the piezoelectric shunt damper system is to be validated. The terminal of the piezoelectric patch is now connected to the optimal shunt circuit constructed as discussed in Section 4. For implementation of the synthetic inductor, a DC power supply is required to supply voltage to the LM358P op-amps. The experiment is performed by supplying sine-wave input to the beam-PSD system through the electromagnetic shaker, capturing the first resonance of the beam. The response of the beam is collected when the piezoelectric terminal is in open-circuit condition (without damping) and when the terminal is connected to the optimal shunt circuit (with damping), respectively.

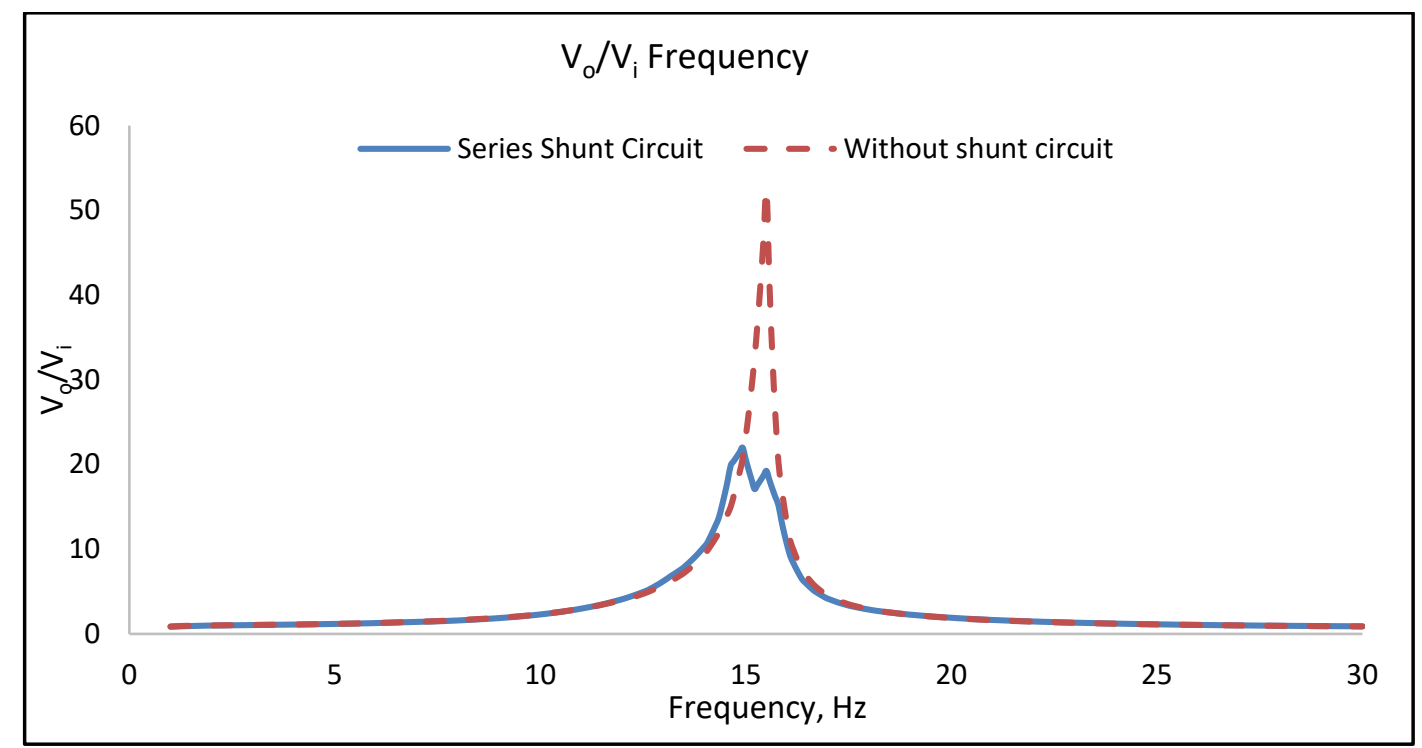

Fig. 8: Experimental result on the vibration response of the beam-PSD with damping (bluesolid) and without damping (red-dashed).

Figure 8 shows the vibration response of the cantilever beam at its first resonant frequency denoted by the ratio of output and input voltages $\left(V_{o} / V_{i}\right)$ from the accelerometer located at the beam tip (output from the system) and at the beam clamp (input to the system), respectively. Two measurements are taken, i.e. in open-circuit and closed-circuit condition, and the data is plotted on the same graph for comparison. Reduction of vibration can be seen at the first resonant peak, calculated to be $67.4 \%$. The comparison of the PSD performance from simulation and experiment is shown in Table 3 . It can be concluded that the constructed enhanced optimal shunt circuit manages to dissipate energy from its host structure successfully, and therefore validated the results from simulation studies conducted.

Table 3: The performance of the vibration reduction using optimum $R L$ values.

\begin{tabular}{cccc}
\hline Technique & 1st nat. freq. & Amplitude at 1st nat. freq. & $\begin{array}{c}\text { Vibration } \\
\text { reduction } \\
\text { percentage, \% }\end{array}$ \\
\hline $\begin{array}{cccc}\text { Simulation } \\
\text { (COMSOL) }\end{array}$ & $15 \mathrm{~Hz}$ & $\begin{array}{c}16.3 \mathrm{~mm}(\text { disp. }) \text { - no damping } \\
4.9 \mathrm{~mm}(\text { disp. }) \text { - with damping }\end{array}$ \\
Experiment & $15.2 \mathrm{~Hz}$ & $\begin{array}{c}52.4\left(V_{o} / V_{i}\right)-\text { no damping } \\
17.1\left(V_{o} / V_{i}\right)-\text { with damping }\end{array}$ & 67.4 \\
\hline
\end{tabular}




\section{CONCLUSION}

In this work, a piezoelectric shunt damper with enhanced synthetic inductor is used to damp the first resonance of a cantilever beam, which is shown both in simulation and via experiment. The optimal resistance and inductance values for the shunt circuit are found to be $R=78.28 \mathrm{k} \Omega$ and $L=2.9 \mathrm{kH}$, respectively. Due to the significantly large value of inductance required, a synthetic inductor is utilized and enhanced by introducing a polarized capacitor attached in parallel to the synthetic inductor to avoid impedance mismatch. Finally, the series shunt circuit is tested and it is found that the vibration reduction achieved is $67.4 \%$ experimentally which agrees with the simulation study.

\section{ACKNOWLEDGEMENT}

This research is funded by the Ministry of Higher Education Malaysia grant no. IRAGS18020-0021.

\section{REFERENCES}

[1] Hagood NW, von Flotow A. (1991) Damping of structural vibrations with piezoelectric materials and passive electrical networks. Journal of sound and vibration, 146(2): 243-268.

[2] Chatziathanasiou, G., Chrysohoidis, N., Kostas, G., \& Saravanos, D. A. (2021). Semi-Active Vibration Control of Aircraft Structures. In AIAA Scitech 2021 Forum (p. 1736).

[3] Pernod, L., Lossouarn, B., Astolfi, J. A., \& Deü, J. F. (2021). Vibration damping of marine lifting surfaces with resonant piezoelectric shunts. Journal of Sound and Vibration, 496, 115921.

[4] Yun, Y. S., Kim, J. C., Noh, H. M., \& Kim, M. S. (2021). Reduction in High-Frequency Wheel Noise/Vibration of Railway Vehicles Using Piezoelectric Shunt. International Journal of Precision Engineering and Manufacturing - Green Technology, 8(3), 981-995.

[5] Mohammadi A. (2017) Passive vibration control of a cantilever beam using shunted piezoelectric element. 5th RSI Int. Conf. Robot. Mechatronics, no. IcRoM, pp. 389-393.

[6] Park, C. H. (2003). Dynamics modelling of beams with shunted piezoelectric elements. Journal of Sound and Vibration.

[7] Jeon, J. Y. (2009). Passive vibration damping enhancement of piezoelectric shunt damping system using optimization approach. Journal of Mechanical Science and Technology.

[8] Lossouarn, B., Aucejo, M., Deü, J. F., \& Multon, B. (2017). Design of inductors with high inductance values for resonant piezoelectric damping. Sensors and Actuators A: Physical, 259, 68-76.

[9] Mayer, D., Linz, C., \& Krajenski, V. (2015). Synthetic inductor for passive damping of structural vibrations. In 7th ECCOMAS Thematic Conference on Smart Structures and Materials. SMART.

[10] Park CH, Inman DJ. (2003), Enhanced piezoelectric shunt design. Shock Vib., 10(2):127-133.

[11] Fleming, A. J., Behrens, S., \& Moheimani, S. O. R. (2003). Reducing the inductance requirements of piezoelectric shunt damping systems. Smart Materials and Structures.

[12] American and Standard. (1998) IEEE Standard on Piezoelectricity: An American National Standard. ANSI/IEEE Std 176-1987

[13] Wahid AN. Muthalif AG, Nor KA. (2016) Investigating negative capacitance shunt circuit for broadband vibration damping and utilizing ACO for optimization. Int. J. Circuits Electron, 1: 168-173.

[14] Marakakis, K., Tairidis, G. K., Koutsianitis, P., \& Stavroulakis, G. E. (2019). Shunt piezoelectric systems for noise and vibration control: A review. In Frontiers in Built Environment. 